Mitteilungen der Österreichischen Geographischen Gesellschaft, 161. Jg., S. 161-188

(Annals of the Austrian Geographical Society, Vol. 161, pp. 161-188)

Wien (Vienna) 2019, https://doi.org/10.1553/moegg161s161

\title{
RÄUMLICHE ANALYSE
}

SPATIAL ANALYSIS

\section{Analysis of Romanian Polycentricity Based on Functional Urban Areas}

\author{
Sorin Daniel Manole, Piteşti, Antonio Valentin TACHE, Bucharest [București], \\ Vasile MeIŢĂ, Bucharest [București] and Alexandru-Ionuţ PETRIŞOR, \\ Bucharest [București] (all Romania)* \\ Initial submission / erste Einreichung: 07/2018; revised submission / revidierte Fassung: 12/2018; \\ final acceptance / endgültige Annahme: 01/2019 \\ with 4 figures and 4 tables in the text
}

\section{CONTENTS}

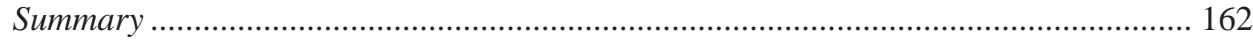

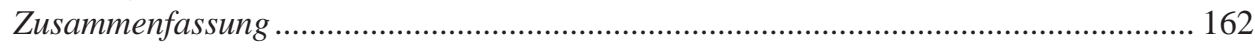

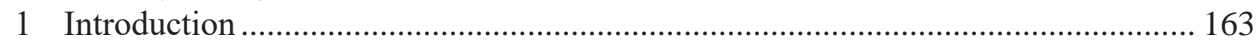

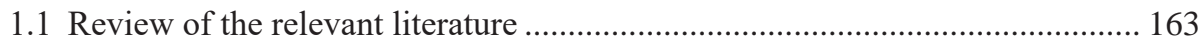

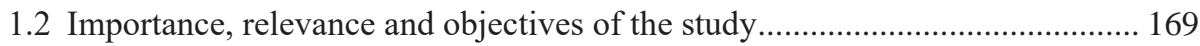

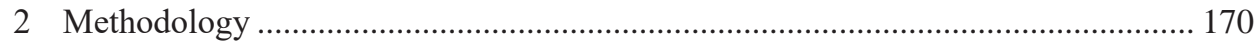

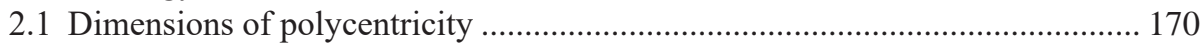

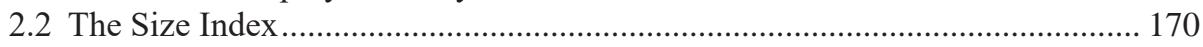

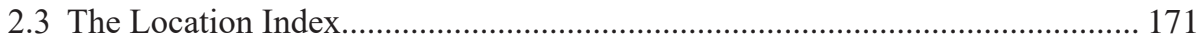

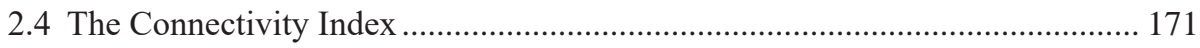

\footnotetext{
* Sorin Daniel Manole PhD, Associate Professor, "Constantin Brâncoveanu” University, Calea Bascovului nr. 2A, cod 110095, Piteşti, Romania; Antonio Valentin TACHE, Senior Researcher 3, National Institute for Research and Development in Constructions, Urbanism and Sustainable Spatial Development URBAN-INCERC, Şoseaua Pantelimon, no. 266, sector 2, cod 021652, Bucharest, Romania; Vasile MeIŢĂ PhD, Senior Researcher 1, General Director, National Institute for Research and Development in Constructions, Urbanism and Sustainable Spatial Development URBAN-INCERC, Şoseaua Pantelimon, no. 266, sector 2, cod 021652, Bucharest, Romania; Alexandru-Ionuţ Petrişor PhD, PhD Habil., Associate Professor and Director, Doctoral School of Urban Planning, „Ion Mincu” University of Architecture and Urbanism, str. Academiei nr. 18-20, 010014, Bucharest, Romania. Emails: danielsorinmanole@yahoo.com, tonytache62@gmail.com, vasile.meita@gmail.com, alexandru.petrisor@uauim.ro
} 


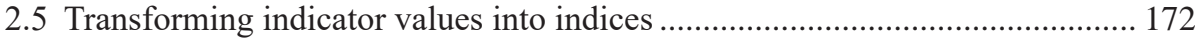

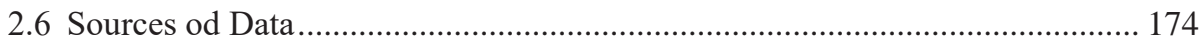

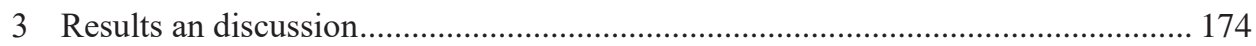

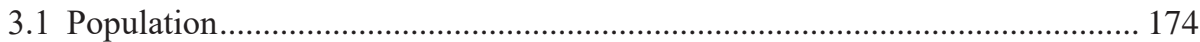

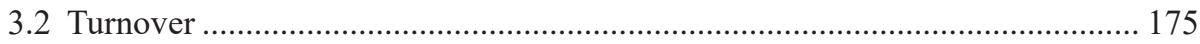

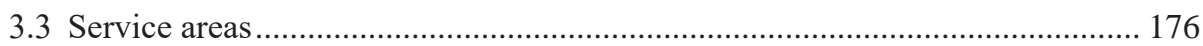

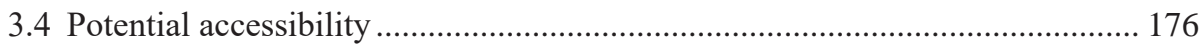

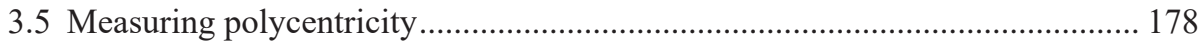

3.6 The strength of the relationship between potential accessibility, turnover and

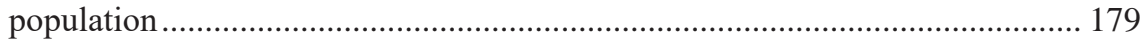

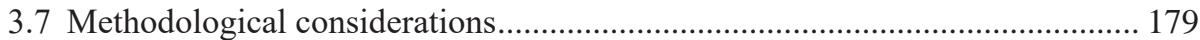

3.8 Limitations and future directions.............................................................. 180

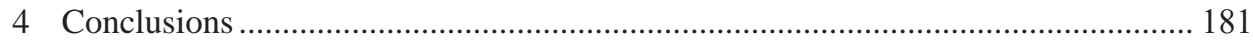

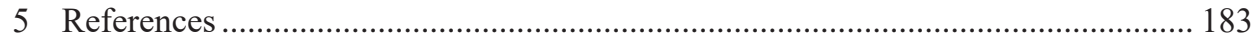

\section{Summary}

A polycentric network consists of urban functional areas with significant growth potential in the settlement network and a transport infrastructure that effectively interconnects them. Polycentric development is a key instrument for promoting economic competitiveness, social cohesion and environmental sustainability, and its assessment has a particular importance for the European strategies. The paper aims to assess the level of polycentricity of Romania based on a methodology developed by changing the one used in ESPON 1.1.1 by replacing the GDP with the turnover, multimodal accessibility with accessibility, and using a threshold of 30,000 inhabitants instead of 50,000 for the centres of functional urban areas. The results, consisting of country rankings based on size, location, connectivity, and polycentricity, were compared to those of ESPON 1.1.1. Romania ranked fifth in the top from the Polycentricity Index of ESPON countries, with a medium high level of polycentricity.

Keywords: Polycentricity, polycentricity aggregated indexes, polycentricity global index, functional urban areas, ESPON, Romania

\section{Zusammenfassung}

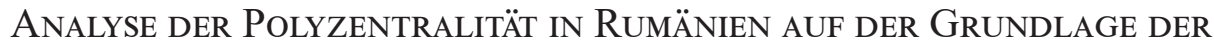 FUNKTIONALEN VERFLECHTUNG VON STADTREGIONEN}

Ein polyzentrisches Netzwerk besteht aus städtischen Funktionsverflechtungen mit erheblichem Wachstumspotenzial im Siedlungsnetz und einer Verkehrsinfrastruktur, die die einzelnen städtischen Gebiete effektiv miteinander verbindet. Die polyzentrische Entwicklung ist ein Schlüsselinstrument zur Förderung der wirtschaftlichen Wettbewerbsfähigkeit, des sozialen Zusammenhalts und der ökologischen Nachhaltigkeit, und ihre Bewertung ist für die europäischen Strategien von besonderer Bedeutung. Das Papier zielt darauf ab, das Ausmaß der Polyzentralität Rumäniens auf der Grundlage einer Methodik zu bewerten, 
die durch die Änderung des in ESPON 1.1.1 verwendeten Konzepts ersetzt wurde, indem das BIP durch den Umsatz, multimodale Zugänglichkeit durch die Zugänglichkeit ersetzt wurde, und zwar unter Verwendung einer Schwelle von 30.000 Einwohnern statt wie bei ESPON 50.000 für die Zentren der funktionalen städtischen Gebiete. Die Ergebnisse, bestehend aus Länderrankings basierend auf Größe, Standort, Konnektivität und Polyzentralität, wurden mit denen von ESPON 1.1.1 verglichen. Rumänien rangiert im Polyzentralitätsindex der ESPON-Länder an fünfter Stelle mit einer mittleren Polyzentralität.

Schlagwörter: Polyzentralität, Polyzentralitätsaggregate, Polyzentalitätsindex, funktionale Stadtgebiete, ESPON, Rumänien

\section{Introduction}

The Romanian territorial development strategy is titled "A Polycentric Romania - 2035", because it is aimed at developing a more polycentric structure in Romania. For this goal, the results and methodology of ESPON Project 1.1.1 (cf. Nordregio 2004; DüHR 2005) are an important reference. Thus, in order to achieve the goal, this study answers two research questions: (1) how polycentric the country already is, and (2) whether it has become more polycentric since the completion of the program. For this purpose, given the many changes that occurred after this moment, the introduction performs an analysis of the perceived benefits of polycentricity in the Romanian context and a review of the different approaches to measure, and, based on them, adapts the ESPON Project 1.1.1 to the current conditions, discussing the results in an attempt to answer the research question. The approach allows for a better comparison of the results obtained by ESPON Project 1.1.1 and the current situation, but also for suggesting a better measurement to trace future development towards polycentricity.

Polycentricity is the focus of modern policies and spatial development objectives at national and European level (Egnatia Odos Observatory 2010). Some years ago, the results of a questionnaire have shown that 18 of the 29 countries within the ESPON Space had a polycentric development in one way or another (Nordregio 2004). Polycentric spatial development is seen in Europe as a tool to ensure a more balanced (BREZZI and VENERI 2015), competitive and sustainable territorial development (CSD 1999). The balance is ensured by reducing the territorial gaps (DOBRIN et al. 2010a, b; MANOLE et al. 2011, 2012; IANOŞ et al. 2013; MANIĆ et al. 2016; SîRODOEV et al. 2017). The concept of polycentricity replaces the core-periphery model (PETRIŞOR 2017), thus marking a paradigm change in thinking Europe's spatial and economic structure (MEIJERs et al. 2005). All these show the importance of polycentricity analyses performed at a national level.

\subsection{Review of the relevant literature}

Numerous studies in the international literature, aimed at quantifying the concept, present a wide variety of views and approaches, which shows a lack of consensus about the man- 
ner of assessing polycentricity. This is because polycentricity is a fuzzy, unclear concept (ESKelinen and Fritsch 2009; TAubenböcK et al. 2017; Davoudi 2003; SHAW and SyKeS 2004; Burgalassi 2010; MeIJERS et al. 2007). Moreover, polycentric development means different things to different actors and at different scales (HAGUE and KiRK 2003; Davoudi 2003; Kloosterman and Musterd 2001; Faludi 2001).

Polycentricity provides a reference frame for thinking about the territorial development applicable at different spatial scales and in essence "describes the interconnections and mutual interdependence that exist or may develop between places" (SHAW and SYKES 2004). An urban system is polycentric if there is no major urban centre (i.e. population or resource are not concentrated), centres' sizes do not differ too much, and centres have functional relationships, promoting a uniform spatial distribution (PALMA et al. 2015). A polycentric situation occurs when several cities have functions that complement each other and have links to one another, which sets three prerequisites for polycentricity: functions, flows and cooperation (GlanZMANN et al. 2004). According to AligiCA and TARKo (2012), polycentricity is defined as a non-hierarchical institutional and cultural framework that makes possible the coexistence of multiple centres of decision making with different objectives and values, and sets up the stage for an evolutionary competition between the complementary ideas and methods of these centres, which can act either on the same territory or can be territorially delimited from each other in a mutually agreed manner.

According to RaUHUT (2016), "polycentricity is a concept rooted in many scientific disciplines, but also a political concept” (cf. Fig. 1).

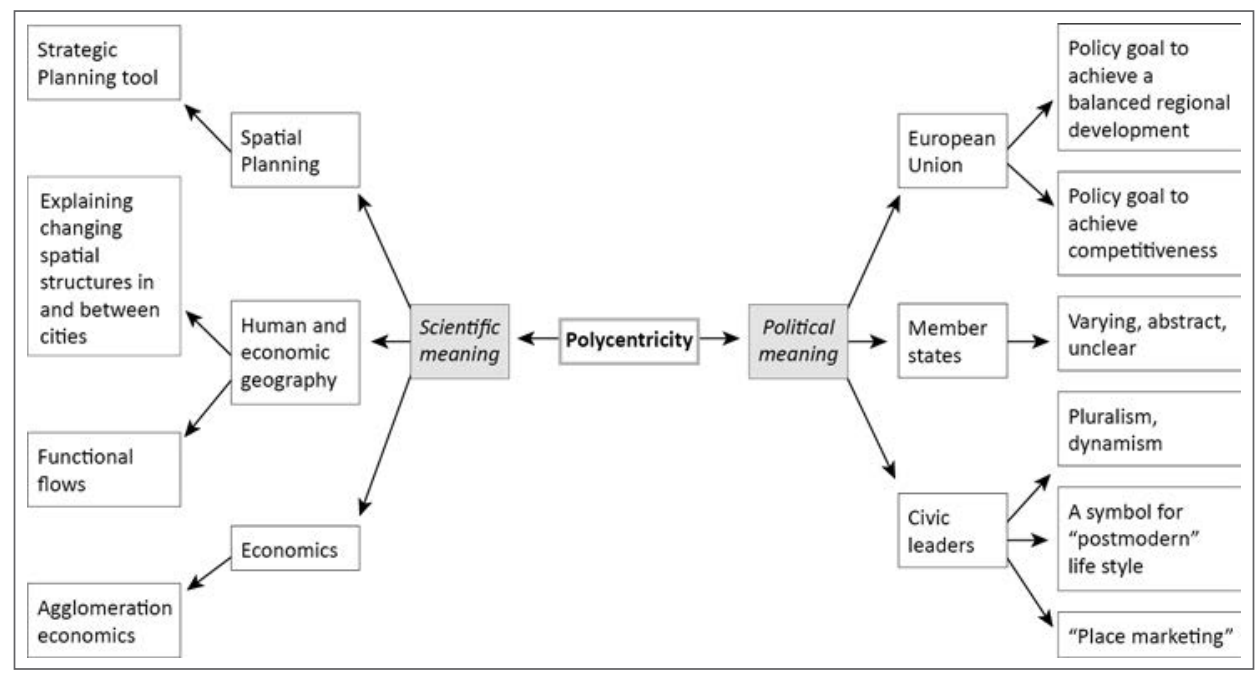

Source: RAUHUT 2016

Figure 1: Scientific and political meanings of polycentricity

Polycentricity is characterised by two structural aspects: morphological and functional or relational (Nordregio 2004; Egnatia Odos Observatory 2010; WegENER 2013; Burger 
and MeiJers 2012; Burgalassi 2010), to which some authors added the third one, called governance (DÜHR and NADIN 2005) or policy target (RePUS 2007). The morphological component of polycentricity consists of the size and distribution of urban centres across space (Rauhut 2016; MeiJers and SANDberg 2006; SANDberg and Meijers 2006; BrezzI and Veneri 2015). Functional polycentricity implies a spatial organisation in terms of functional interconnectedness (RAUHUT 2016; Nordregio 2004; IPENBURG and Lambregts 2001; Kloosterman and Musterd 2001). Polycentricity has been measured based on the definition of the polycentric urban system by detailing the two distinct aspects that characterise polycentricity: morphology and functionality (MASIP-TRESSERRA 2016, p. 192).

Morphological polycentricity is associated with a balanced distribution in terms of the development of centres. Most often, the morphological polycentricity is measured by the slope of the regression line of the rank-size distribution of the urban centres across the territory or the functional urban areas. The most commonly used indicators of size are: population (Nordregio 2004; Egnatia Odos Observatory 2010; MEIJERS and SANDBERG 2008; Brezzi and Veneri 2015; Meijers and SANDBERg 2006; Wegener 2013; MeiJers et al. 2007; SANDBERg and MeiJers 2006; MeIJers and Burger 2010; Burgalassi 2010; Veneri and Burgalassi 2011), GDP (Nordregio 2004; Egnatia Odos Observatory 2010; Wegener 2013; Meijers et al. 2007), jobs (Burger and Meijers 2012), and shoppers (Burger and MeIJERs 2012).

All functional urban areas from the regression line of the rank-size distribution within the analysed territory are used, or possibly the largest is excluded. It has been argued that this approach leads to a higher degree of polycentricity than in reality if the considered territory has a large number of smaller functional urban areas. Therefore, it has been suggested that a sample of the largest geographical units in the territory could be used for the regression line of the rank-size distribution. For example, MeIJERs and SANDBERG (2006) have computed functional polycentricity based on the ten most populated cities in the country; MeIJERs (2008) has proposed the use of the largest 2, 10 or 20 geographical units, VENERI and BURGALASSI (2012) have taken into account all cities whose populations are larger than the median population in the urban system, BURGER et al. (2014a) have considered samples of the largest 2, 3 and 4 centres, and BREZZI and VENERI (2015) have used the rank-size distribution of the four main functional urban areas - to review some examples.

Because a polycentric urban system is not dominated by a centre, the following indicators for measuring the degree of dominance of the largest centre in the system have been proposed in order to assess morphological polycentricity: the degree by which the size of the largest geographical unit deviates from the regression line of the rank-size distribution of population and GDP (Nordregio 2004; Egnatia Odos Observatory 2010; WeGENER 2013; MeIJERs et al. 2007), the ratio of the population of the main city to the total population of the analysed territory (VENERI and BuRgalassi 2012; BREZZI and VENERI 2015), the cardinal ranking of functional urban areas based on five indicators (IGEAT et al. 2007), and the ratio of the size of the largest functional urban area and the average of functional urban areas' sizes (MANOLE 2017). 
Similarly, starting from the idea that polycentricity implies a uniform spatial distribution of cities over the territory, the ratio between the number of NUTS 2 regions with a large city and the total number of NUTS 2 regions has been considered a measure of morphological polycentricity, since the number of large cities is equal to the number of NUTS 2 regions (SAndberg and Meijers 2006; MeiJers and SANDberg 2006; 2008). In order to highlight the distribution of cities within the territory, taking into account the fact that a polycentric urban system must have its centres equally spaced from each other, the Gini coefficient of service areas has been used to measure the morphological polycentricity (Nordregio 2004).

The quantification of the level of functional polycentricity uses more indicators than the measurement of morphological polycentricity. The functional dimension of polycentricity involves two aspects: the distribution of flows and the spatial integration (LAMBREGTS 2009; Burger 2011; Burger and MeIJERs 2012). Some researchers believe that functional polycentricity is also characterised by complementarity (CHAMPION 2001; KLOOSTERman and Lambregts 2001; Parr 2004; Burgalassi 2010; Masip-Tresserra 2016).

The first aspect is the distribution of functional links between the centres of urban systems. An urban structure can be considered polycentric when there are two-way flows between centres, i.e. the distribution of flows is balanced. Several indicators have been used to quantify the distribution of flows.

LIMTANAKOOL et al. $(2007 ; 2009)$ have introduced the following indicators to describe the symmetry and the structure of the spatial systems: the Node Symmetry Index (the ratio of the difference between the input flows and output flows to the total flows for the node), the Link Symmetry Index, and, respectively, the Entropy Index (which measures how the total interaction is distributed between centres) end entropy indices for entries, for exits and at node level. The average value and the standard deviation of nodal symmetry indices for centres belonging to an urban system provide information on the direction of flows between cities. In several studies, the degree of polycentricity has been determined based on the entropy using business, leisure and holiday flows in France and Germany (LimTANAKool et al. 2007), commuting and leisure flows in the Netherlands (LimtanaKool et al. 2009) and daily commuting flows in Italy (VENERI and BURGALASSI 2012).

VAN DER LAAN (1998) and PATUelli et al. (2010) have used the inward openness (the ratio between the number of employees of a centre living in other centres and the total number of employees of that centre) and the outward openness (similarly defined) to study the commuting in the Netherlands and Germany. Also, the dominance measures have been used in order to determine the degree to which the functional linkages are bidirectional (IGEAT et al. 2007; Hall and PAin, 2006; Burger et al. 2011). Similarly, in order to assess the degree of functional balance, the notion of centrality of a given centre, defined as the total number of incoming flows from other locations within the same urban system has been introduced (BURGER and MEIJERS 2012) and centre-specific centrality scores determined (Burger et al. 2011; Burger and MeiJers 2012). At the same time, the balanced distribution has been measured using two indicators: the primacy functional index, computed as the ratio of in-flows to the principal city to the total in-flows of the urban system (BURGER et al. 2011) and the slope of the regression line of rank-size distribution 
of centrality values (MeiJers and Burger 2010; Burger and MeiJers 2012; Burger et al. 2014b).

Recent studies have measured the balance of the distribution of centres across the urban system through the connectivity field method, introduced by VASANEN (2012). The connectivity field shows the extent to which each centre is functionally connected to the remaining parts of the urban system. The connectivity field of a centre consists of the distribution of origins of all in-flows to that centre. The connectivity field from the distribution of out-flows destinations is built up in a similar manner. The balance of the distribution of centres across the urban system is measured by the slope of the regression line between the connectivity value of each centre and its distance to the central city.

The second aspect of functional polycentricity is spatial integration. This facet of polycentricity addresses both the strength of functional linkages among centres and the degree to which the centres are interdependent within the urban system (MASIP-TRESSERRA 2016). In a polycentric urban structure that is spatially integrated, the flows between them do not differ significantly from the total potential flows for any set of centres. Several methods have been proposed in order to evaluate the degree of spatial integration.

LimtanAKool et al. $(2007 ; 2009)$ have proposed the Dominance Index of a node, which measures to what extent the city attracts flows from the other centres, with respect to the average degree of "attractiveness" of the urban system (TACHE et al. 2017), in order to describe the strength of the spatial systems. The Dominance Index is required to classify cities and to determine the strength of the hierarchy, which indicates whether a system is polycentric. VAN NUFFEL et al. (2010) have adapted and extended the set of functional polycentricity indicators suggested by LIMTANAKOOL et al. $(2007 ; 2009)$ using standard deviations and normalisation to control the sensitivity to the number of cities and links and applied them to data on air passenger flows within Europe.

Furthermore, the degree of connectivity of a centre is also evaluated by the coefficient of determination for linear regression between the centre connectivity field and the potential field, consisting of the distribution of the total number of origin locations (VASANEN 2013). The overall level of spatial integration is expressed by the average of the coefficients of determination values of all centres in the urban system.

GrEEN $(2005 ; 2007)$ has defined network density as ratio of the number of flows in the network and theoretically possible maximum number of flows in the network. Another measure of spatial integration is the average connectivity or centrality values of all centres in the urban system (Meijers and Burger 2010; Burger and MeiJers 2012).

Another approach has been to evaluate the degree of spatial integration through a gravity model (VAN OorT et al. 2010; DE GoeI et al. 2010; HANSSENS et al. 2014; CHAMPION and CoOmbes 2014; KaUfFMANN 2016). The method consists in estimating a gravity model (analogous to Newton's law of universal gravitation), which expresses the dependence of interaction intensity between two spatial units on the power of their size and distance between them.

There are studies which assessed both the distribution of flows and spatial integration through a functional polycentricity index. GREEN $(2005 ; 2007)$ has proposed the Ordinary Polycentricity, Special Functional Polycentricity and General Functional Polycentricity to evaluate functional polycentricity. These indicators have been used to determine the level 
of functional polycentricity in several articles: Special Functional Polycentricity - for the Italian NUTS 3 regions (VENERI and BURGALASSI 2011), Ordinary Polycentricity - for the Italian NUTS 2 regions (VENERI and BURGALASSI 2012), and General Functional Polycentricity - for three regions in southern Chile (Maturana and ARENAS 2012). In addition to them, in the ESPON Project 1.1.1 (Nordregio 2004, p. 61), functional polycentricity has been measured by the Connectivity Index, computed based on two indicators: the slope of the regression line between the multimodal accessibility and the decimal logarithm of population of functional urban areas, and the Gini coefficient of multimodal accessibility of functional urban areas.

The third aspect of functional polycentricity (complementarity) is more ambiguously conceptualised and less studied in the literature than the other aspects. Two cities are complementary if they have different specialisations, so that each one provides services to businesses or citizens located in the other (MeIJERs 2005; 2007). Thus, complementarity means a spatial division of labour as a result of the specialisation processes and demand and supply. In order to evaluate the complementarity, different studies have proposed correspondence techniques (MeiJers 2005; 2007; Cowell 2010; Franz and HORNYCH 2010), a complementarity index (VAN OORT et al. 2010), and a competition indicator (BURGER et al. 2013).

There are few methodologies that have proposed composite indicators for quantifying polycentricity at the national level. Apart from the Polycentricity Index produced by the ESPON Project 1.1.1 (Nordregio 2004), the other indices have embedded only certain aspects of polycentricity. In fact, most attempts to measure polycentricity at a global level have only addressed morphological aspects, such as IGEAT et al. (2007), MeIJER and SANDBERG (2008), Brezzi and Veneri (2015). It should also be mentioned that MANole et al. (2018) have analysed the Romanian polycentricity by applying the methodology presented in this paper and using the functional urban areas determined on the basis of data on daily commuting (as an indicator of sub-urbanisation, according to IANOş 2017 and KUREK et al. 2017) and dynamics of population and number of employees.

The ESPON Project 1.1.1 (Nordregio 2004) has performed an in-depth analysis of polycentricity and polycentric urban systems. The Polycentricity Index created by the project "has probably had the largest impact on the conceptualization of what is a polycentric and monocentric Europe" (RAUHUT 2016). This polycentricity index has been computed based on seven indicators, previously presented, five of a morphological type, and two of a relational type.

The ESPON program has provided a plethora of information, indicators and reports on the functional urban areas at European level. However, due to the diversity of functional urban areas determined by the size and specificity of the EU member states, these studies have not provided sufficient information on the planning and management of these areas in order to phrase appropriate policies for maximising their potential.

In summary, the literature review identified an important number of methodological approaches and indicators for measuring polycentricity. While the choice of indicators depends on the scale of measuring polycentricity (this study is designed for the national level), each method has its advantages and disadvantages; they are summed up in Table 1. 


\begin{tabular}{|c|c|c|}
\hline Method & Advantages & Disadvantages \\
\hline $\begin{array}{l}\text { Slope of the regression line of the rank-size } \\
\text { distribution of the urban centres across the } \\
\text { territory or the functional urban areas } \\
\text { (Nordregio 2004; Egnatia Odos Observatory } \\
\text { 2010; MEIJERS and SANDBERG 2008; BREZZI } \\
\text { and VENERI 2015; MEIJERS and SANDBERG } \\
\text { 2006; WEGENER 2013; MEIJERS et al. 2007; } \\
\text { SANDBERG and MEIJERS 2006; MEIJERS and } \\
\text { BURGER 2010; BURGALASSI 2010; VENERI and } \\
\text { BURGALASSI 2011; BURGER and MEIJERS 2012) }\end{array}$ & $\begin{array}{l}\text { provides the best } \\
\text { way to measure } \\
\text { morphological } \\
\text { polycentricity; } \\
\text { can be easily com- } \\
\text { puted using different } \\
\text { software (EViews, } \\
\text { SPSS, Excel, etc.). }\end{array}$ & $\begin{array}{l}\text { allows for determin- } \\
\text { ing the regression } \\
\text { line and, implicitly, } \\
\text { its slope, without } \\
\text { checking the validity } \\
\text { of the model from } \\
\text { the statistical point } \\
\text { of view. }\end{array}$ \\
\hline $\begin{array}{l}\text { Cooperation } \\
\text { (Nordregio 2004; Egnatia Odos Observatory } \\
\text { 2010; SCHÜRMANN et al. 1997; SPIEKERMANN } \\
\text { and SCHÜRMANN 2007; WEGENER et al. 2002; } \\
\text { SPIEKERMANN and WEGENER 2006) }\end{array}$ & $\begin{array}{l}\text { - it is an important } \\
\text { dimension of } \\
\text { polycentricity. }\end{array}$ & $\begin{array}{l}\text { - uses potential } \\
\text { indicators; } \\
\text { - is assessed based } \\
\text { on indicators that } \\
\text { can only capture } \\
\text { certain aspects of } \\
\text { cooperation. }\end{array}$ \\
\hline $\begin{array}{l}\text { Complementarity } \\
\text { (MEIJERS 2005; 2007; COWELL 2010; FrANZ } \\
\text { and HORNYCH 2010; VAN OORT et al. 2010; } \\
\text { BuRGER et al. 2013) }\end{array}$ & $\begin{array}{l}\text { - it is a relevant } \\
\text { dimension of } \\
\text { polycentricity. }\end{array}$ & $\begin{array}{l}\text { - the concept has } \\
\text { more than a single } \\
\text { meaning; } \\
\text { the indicators used } \\
\text { measure only } \\
\text { certain aspects of } \\
\text { complementarity. }\end{array}$ \\
\hline $\begin{array}{l}\text { Distribution of cities over territories } \\
\text { (Nordregio 2004; MANOLE et al. 2018; SAND- } \\
\text { BERG and MEIJERS 2006; MEIJERS and SAND- } \\
\text { BERG 2006; 2008) }\end{array}$ & $\begin{array}{l}\text { - it is perhaps the most } \\
\text { important dimension } \\
\text { of polycentricity; } \\
\text { - the use of the Gini } \\
\text { coefficient of the } \\
\text { service area sizes is } \\
\text { a relevant procedure. }\end{array}$ & $\begin{array}{l}\text { the use of the ratio } \\
\text { between the number } \\
\text { of regions includ- } \\
\text { ing a large city and } \\
\text { the total number } \\
\text { of regions is a less } \\
\text { relevant procedure. }\end{array}$ \\
\hline
\end{tabular}

Source: Created by the authors based on the review of the relevant literature

Table 1: Comparison of the different approaches used for measuring polycentricity

\subsection{Importance, relevance and objectives of the study}

As we have previously detailed, the only substantial approach for assessing the degree of polycentricity at the national level, under a multitude of aspects, is the one provided by the ESPON Project 1.1.1 (Nordregio 2004). Our study is necessary because it improves the original methodology and operates some changes in order to improve the quality of the Polycentricity Index. Furthermore, the study answers to the general Romanian territorial development goal to draft a polycentric development strategy, able to set the national grounds for the priorities, goals and requirement of a functionally efficient polycentric network, directly correlated with the regional and local strategies (KORCELLI-OLEJNICZAK 
2015). From a methodological perspective, the computation of a polycentricity index with three components (size index, location index, connectivity index) is relevant for assessing the accessibility and economic potential of the urban polycentric system in the particular conditions of Romania; the methodological novelty consists of adapting to these particular settings the methodology for computing the national polycentricity used in ESPON 1.1.1 (Nordregio 2004).

\section{Methodology}

\subsection{Dimensions of polycentricity}

In order to measure polycentricity, a methodology similar to the approach of ESPON Project 1.1.1 (Nordregio 2004) was used. In order to assess the polycentricity of a country or region, it is necessary first to establish functional urban areas (FUA), i.e. their centres (core) and adjacent commuting areas. These functional urban areas represent the building blocks of a polycentric spatial structure.

According to Nordregio (2004), Egnatia Odos Observatory (2010) and WEGENER (2013), polycentricity has three dimensions: size, location and connectivity, which are characterised by specific indicators. After determining the functional urban areas, indicators of dimensions were computed and converted into utilities, which were aggregated into the three component indices: Size Index, Location Index, and Connectivity Index. The three indices were used to build up a complex index of polycentricity.

\subsection{The Size Index}

Polycentricity implies a more uniform distribution of cities in the territory, in terms of size. It has been empirically demonstrated and has been postulated that the rank-size distribution in a territory is log-linear (PARR 1985; Nordregio 2004; VENERI and BURGALASSI 2012). In Nordregio (2004), the size of functional urban areas has been expressed by their GDP and population. Since there is no data on the settlement GDP for Romania, we considered that the determination of the GDP of the functional urban areas is a good approximation, and used the turnover instead. The turnover of a functional urban area was computed as the sum of the turnover of all companies within. In a similar way, in Egnatia Odos Observatory (2010), GDP computations have used Prefectures as an equivalent for the territorial units.

In order to characterise the population, which is a demographic indicator of size, and the turnover, which is an indicator of economic development, we defined the same two indicators. The first one was the slope of the linear regression between the decimal logarithm of the functional urban areas' size and the decimal logarithm of their position in the size classification - an indicator of the balanced distribution of size (population or turnover). When computing this linear regression, the functional urban area ranked first with respect to the size was excluded. The smaller the modulus of regression slope is, the more 
polycentric is the distribution, and the higher the modulus of slope is, the less polycentric is the distribution. The justification of these aspects is given by the fact that the greater the absolute value of the regression slope is, the greater the dependence of the size on the position in the ranking, and the larger the differences between the sizes of the functional urban areas are.

We determined also the degree by which the size of the functional urban area ranked first in the size classification deviated from this regression line. This indicator is called primacy and computed by dividing the size of the largest functional urban area by the hypothetical size of the area that would be obtained if followed the regression line (measured on the logarithmic scale). A high value of primacy means a large difference between the size of the largest functional urban area and sizes of other functional urban areas, while a small value indicates that the size of the largest functional urban area is close to the sizes of other functional urban areas. In the hypothetical case of an absolutely polycentric system, in which all functional urban areas would have the same population and turnover, the regression slope would be zero and the primacy would be one for both indicators.

\subsection{The Location Index}

A condition for the polycentricity of an urban system is that its cities have a uniform distribution in the territory. Therefore, there is a need to analyse the distribution of functional urban areas centres across the territory. In this regard, service areas, called Thiessen polygons, have been built up by dividing the territory into raster cells of equal size and allocating each cell to the nearest centre of a functional urban area (Nordregio 2004, pp. 59-60). For the association of raster cells with centres, the distance on the national road network was used. The Gini coefficient of inequality was used to measure the inequality of service area sizes. A value of the Gini coefficient close to zero indicates that there are small differences between service area sizes, suggesting a high level of polycentricity. On the other hand, a value of the Gini coefficient close to 1 indicates large differences between service area sizes, and a low level of polycentricity.

\subsection{The Connectivity Index}

An important feature of an urban system is the connectivity among urban centres in terms of service provision, cooperation of local and regional governments, and physical infrastructure connections (DüHR and NADIN 2005). There is a functional division of labour between cities, both between higher-level centres and lower-level centres, as well as between centres at equal levels in the urban hierarchy, and all these imply that even low-level cities need to be well connected (WEGENER 2013). Accessibility is the extent to which spatial separation can be overcome and defines the opportunities of exchanges made available to people and businesses (HoLl 2007).

In order to compute the potential accessibility, one would start from the premises that the attractiveness of a destination increases with its size and that the lower the distance, 
the cost or the travel time is lower. The size of the destination is measured by population indicators if we look at the size of market areas for suppliers of goods and services, or by economic indicators (e.g. GDP or turnover) if we consider the size of market areas for suppliers of high-level business services. In more general terms, accessibility is built using two functions, one representing the activities or opportunities that can be exploited, and the other representing the time, distance, or cost needed to achieve them. In the formula of potential accessibility, they are combined multiplicatively, i.e. each one is weight to the other (SCHÜrmann et al. 1997; SPIEKERMANN and SchÜrmAnn 2007; WEgEner et al. 2002; SPIEKERMANn and Wegener 2006):

where:

$$
A_{r}=\sum_{s} W_{s}^{a} \exp \left(-\beta c_{r s}\right)
$$

$A_{r}=$ accessibility of city $r$;

$W_{s}=$ GDP or population of city $s$ in the considered urban network, - in this study, we preferred the population;

$c_{r s}=$ travel time between cities $r$ and $s$, measured in minutes;

$\alpha, \beta=$ parameters.

The ESPON Project 1.1.1 (Nordregio 2004) uses multimodal accessibility of functional urban areas for measuring connectivity; in this study, we replaced it with the accessibility of functional urban areas centres. The formula above reflects the changes made in this study to the ESPON methodology.

In order to determine accessibility, we used $\alpha=1$ and $\beta=0.005$, as in most of the studies. In ESPON Project 1.1.1, the accessibility also includes airplane transportation. For Romania, this is not relevant because there are no regular aircraft links between the cities (except for four of them), and the price is not adjusted to the Romanian salaries, making the use of airplane unaffordable. The national strategy for territorial development is based especially on roads in the functional urban areas (i.e., max. $60 \mathrm{~km}$ ), and railroads for greater distances. Therefore, the travel times between cities, obtained by traveling on national roads and railroads, were expressed in minutes.

The computation of the Connectivity Index was based on two indicators. The first was the Gini coefficient of accessibility of functional urban areas centres, and the second, the slope of the regression line between the accessibility of functional urban areas centres and the decimal logarithm of the population of these functional urban areas. The interpretation of the values of the two is similar: the flatter the regression line (the lower the slope), the smaller the differences between the accessibilities of the centres of functional urban areas and the lower the Gini coefficient, the lesser the accessibility distribution differs from the even one.

\subsection{Transforming indicator values into indices}

In order to compute the three indices (Size Index, Location Index and Connectivity Index), the values of the seven indicators were first converted into utilities. For each indicator 
two thresholds were defined; one corresponded to the value of the indicator at which the polycentricity was zero, and the other to the value of the indicator at which the polycentricity was 100 . If a value of an indicator ranges between the two thresholds, then the corresponding utility is obtained by linear interpolation. For a value of the sub-indicator outside the interval defined by the two thresholds, the corresponding utility takes the value zero or one hundred.

The threshold values for the seven indicators are given in Table 2. The thresholds for rank-size distribution of population and size of service areas were taken from ESPON Project 1.1.1 (Nordregio 2004, p. 72) and the others were modified. In order to determine the thresholds for the rank-size distribution of turnover, the counties of Romania were considered as functional urban areas, the slope and the primacy were computed for GDP and turnover, and the results compared. Also, in order to modify the thresholds for connectivity, the multimodal accessibility of functional urban areas was determined, the slope and the Gini coefficient were computed, and the results compared with those previously found for accessibility.

\begin{tabular}{|l|c|c|c|c|c|c|c|}
\hline & \multicolumn{2}{|c|}{$\begin{array}{c}\text { Rank-size } \\
\text { distribution of } \\
\text { population }\end{array}$} & \multicolumn{2}{|c|}{$\begin{array}{c}\text { Rank-size } \\
\text { distribution of } \\
\text { turnover }\end{array}$} & $\begin{array}{c}\text { Size of } \\
\text { service } \\
\text { areas }\end{array}$ & \multicolumn{2}{|c|}{$\begin{array}{c}\text { Population } \\
\text { and accessibility }\end{array}$} \\
\cline { 2 - 8 } & Slope & Primacy & Slope & Primacy & $\begin{array}{c}\text { Gini } \\
\text { Coefficient }\end{array}$ & Slope & $\begin{array}{c}\text { Gini } \\
\text { Coefficient }\end{array}$ \\
\hline $\begin{array}{l}\text { Indicator value } \\
\text { at which poly- } \\
\text { centricity is 0 }\end{array}$ & -1.75 & 7.5 & $-2.50^{*}$ & $10^{*}$ & 70 & $2 *$ & $20^{*}$ \\
\hline $\begin{array}{l}\text { Indicator value } \\
\text { at which poly- } \\
\text { centricity is 100 }\end{array}$ & -0.50 & 0 & $-0.75^{*}$ & $0 *$ & 10 & $0 *$ & $0 *$ \\
\hline
\end{tabular}

* - values determined by the authors

Source: ESPON Project 1.1.1 (Nordregio 2004, Table 3.3, p. 72) and own computations performed by the authors

Table 2: Threshold values for sub-indicators

The Size Index and Connectivity Indices were computed by weighted additive aggregation of the corresponding indicators and the Polycentricity Index determined by multiplicative aggregation of the dimensional indices using the same weights as in ESPON Project 1.1.1 (Nordregio 2004, p. 72):

Size Index: total weight: $33.33 \%$

- Population: 50 \%

- Slope of regression line: $20 \%$

- Primacy rate: $80 \%$

- Turnover: $50 \%$

- Slope of regression line: $20 \%$ 
- Primacy rate: $80 \%$

Location Index: total weight: $33.33 \%$

- Gini coefficient of size of service areas

Connectivity Index: total weight: $33.33 \%$

- Correlation of population and accessibility

- Slope of regression line: $50 \%$

- Gini coefficient of accessibility: $50 \%$

\subsection{Sources of data}

The data on the population of Romanian settlements in 2015 were provided by the National Institute of Statistics of Romania. Data on the turnover of the Romanian settlements in 2015 were obtained from the Chamber of Commerce and Industry of Romania. The conversion of Romanian lei (RON) to euro (EUR) was made using the average annual exchange rate for 2015 (http://www.bnr.ro/Cursul-de-schimb-3544.aspx), i.e., 1 Euro $=4.4450$ Lei.

\section{Results and discussion}

The functional urban areas in this paper were determined by approximating them to the "potential urban strategic horizons" (PUSH, according to Nordregio 2004). The lack of LAU2 data on the daily commuting indicator from the official Romanian statistics led to their approximation by the functional urban areas that correspond to a large extent to the metropolitan areas legally constituted in Romania.

\subsection{Population}

After determining the population of functional urban areas, they were ordered descending by size. The following results were obtained from the linear regression of the rank-size distribution of the population of functional urban areas:

Regression equation: $\lg ($ Population $)=3.342575-0.966067 \lg ($ Rank $)$

Slope $=-0.966067$

Primacy rate $=1.009559$

These results and Figure 2 suggest a fairly high degree of polycentricity. The absolute value of the slope of the regression line between the decimal logarithm of the population and the decimal logarithm of the rank is medium high (0.966067), compared to the two thresholds for the indicator. At the same time, the value of primacy (1.009559) shows that the considered urban system is not dominated by a functional urban area, i.e. there is a high degree of polycentricity. 


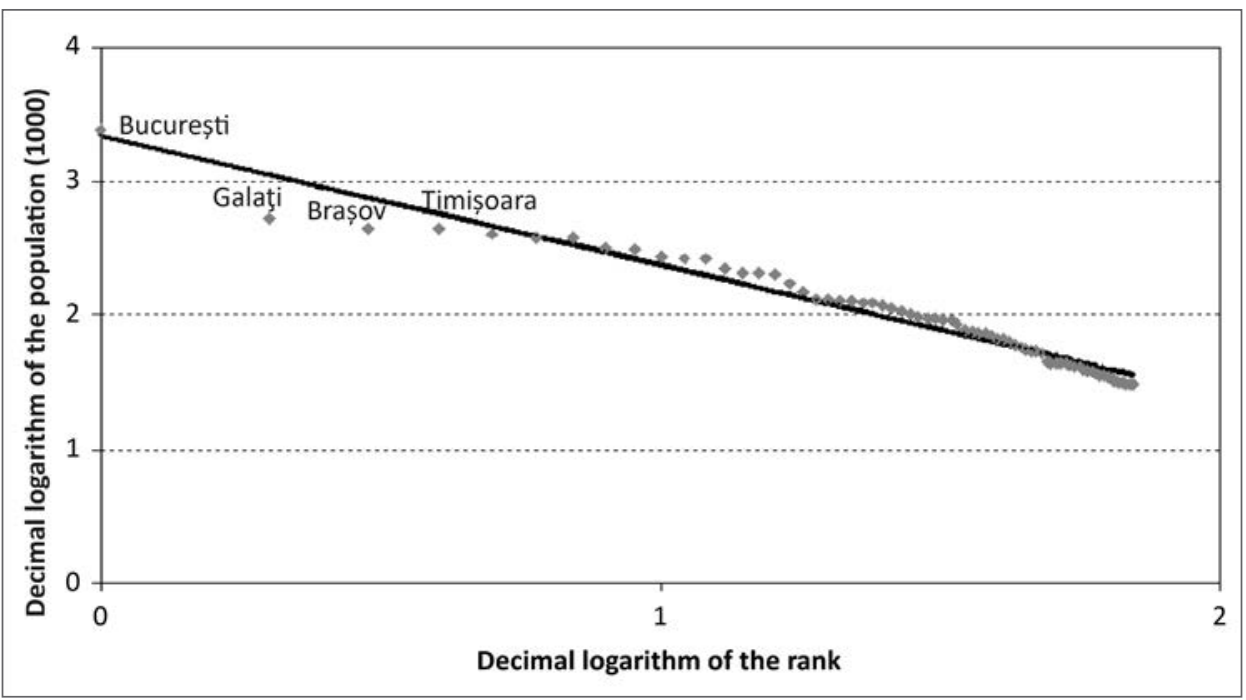

Source: Computed by the authors; own design

Figure 2: Rank-size distribution of population of functional urban areas (FUAs) in Romania

\subsection{Turnover}

Functional urban areas were ranked by their turnover in 2015 (Figure 3). The following results were obtained regarding the linear regression of the rank-size distribution of the turnover of Romanian functional urban areas:

Regression equation: $\lg ($ Turnover $)=5.111954-1.551041 \lg ($ Rank $)$

Slope $=-1.551041$

Primacy rate $=0.980090$

A relatively high level of polycentricity is indicated by the two indicators of the turnover analysed together. More exactly, the slope of the linear regression between the decimal logarithm of the turnover of Romanian functional urban areas and the decimal logarithm of the rank have a medium sized absolute value (1.551041), relative to the two thresholds. However, the primacy, which shows how much the logarithm of turnover of the largest functional urban area deviates from linear regression, is small (0.980090), which indicates a high degree of polycentricity.

The value of the size index (82.4) shows that, similar to the findings of ESPON 1.1.1 (Nordregio 2004), the Romanian system is balanced, consisting of small, average and large cities. At the national level, the secondary cities network is balanced by the seven regional centres, with close sizes, but different with respect to their function. The balanced development is supported first by the cities Bucharest, Constanţa, Braşov, Cluj-Napoca, and Timişoara. However, unlike ESPON 1.1.1, which used the NUTS III GDP, the results 
of this study are based on using the turnover of each LAU II administrative unit; this indicator allowed for computing the turnover of the investigated functional urban areas, and is more accurate for the purpose of comparing them.

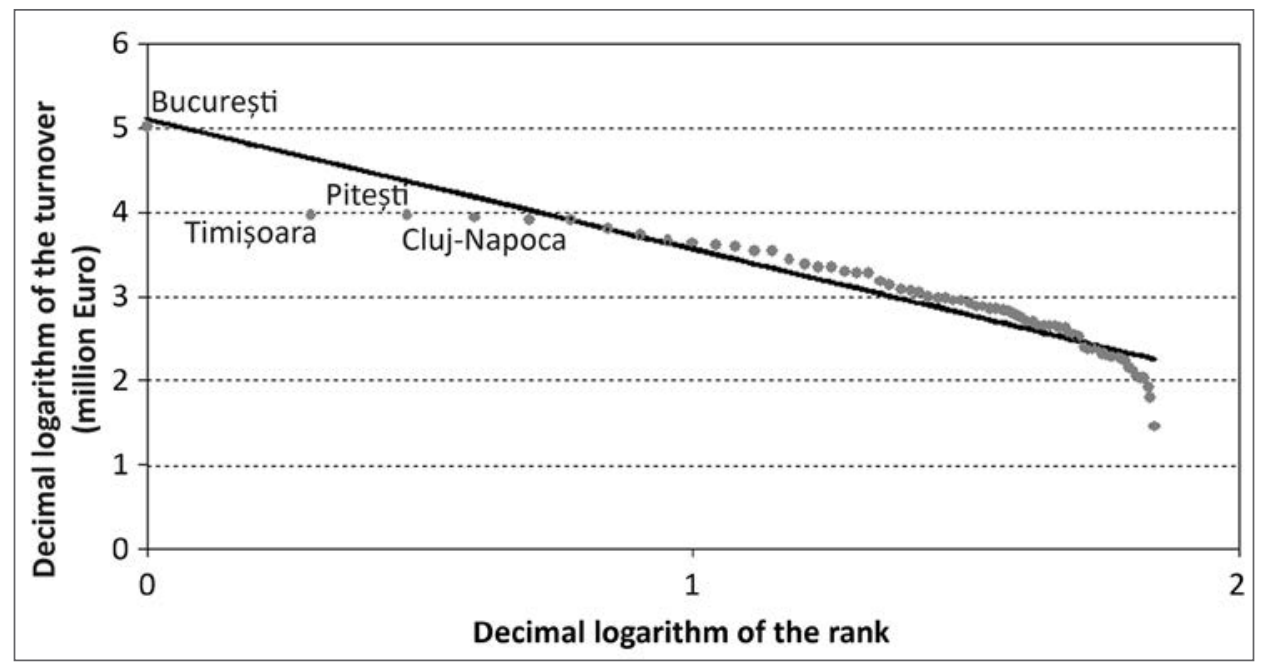

Source: Computed by the authors; own design

Figure 3: Rank-size distribution of turnover of functional urban areas (FUAs) in Romania

\subsection{Service areas}

As can be seen in Figure 4, the service area sizes (the values for these areas were expressed in square kilometres) do not differ too much among them.

The value of the Gini coefficient of the service area sizes is $22.9649 \%$, which means that Romania has a fairly high level of polycentricity in terms of location.

The value of the location index (78.4) indicates a balanced spatial distribution of the cities. This value is constant over time, if the same functional urban areas are analysed. In this study 68 functional urban areas, corresponding to cities over 30,000 inhabitants, were analysed instead of the 59 in ESPON 1.1.1 (Nordregio 2004); this is why the results are slightly different. The difference (nine functional urban areas) could be explained by reassessing the data (Romania provided the original 59 functional urban areas used originally), or the emergence of new functional urban areas in the meantime.

\subsection{Accessibility}

The value of the Gini coefficient of the accessibility of centres of the functional urban areas in Romania is rather small (13.151364\%), but compared to the thresholds, it implies 


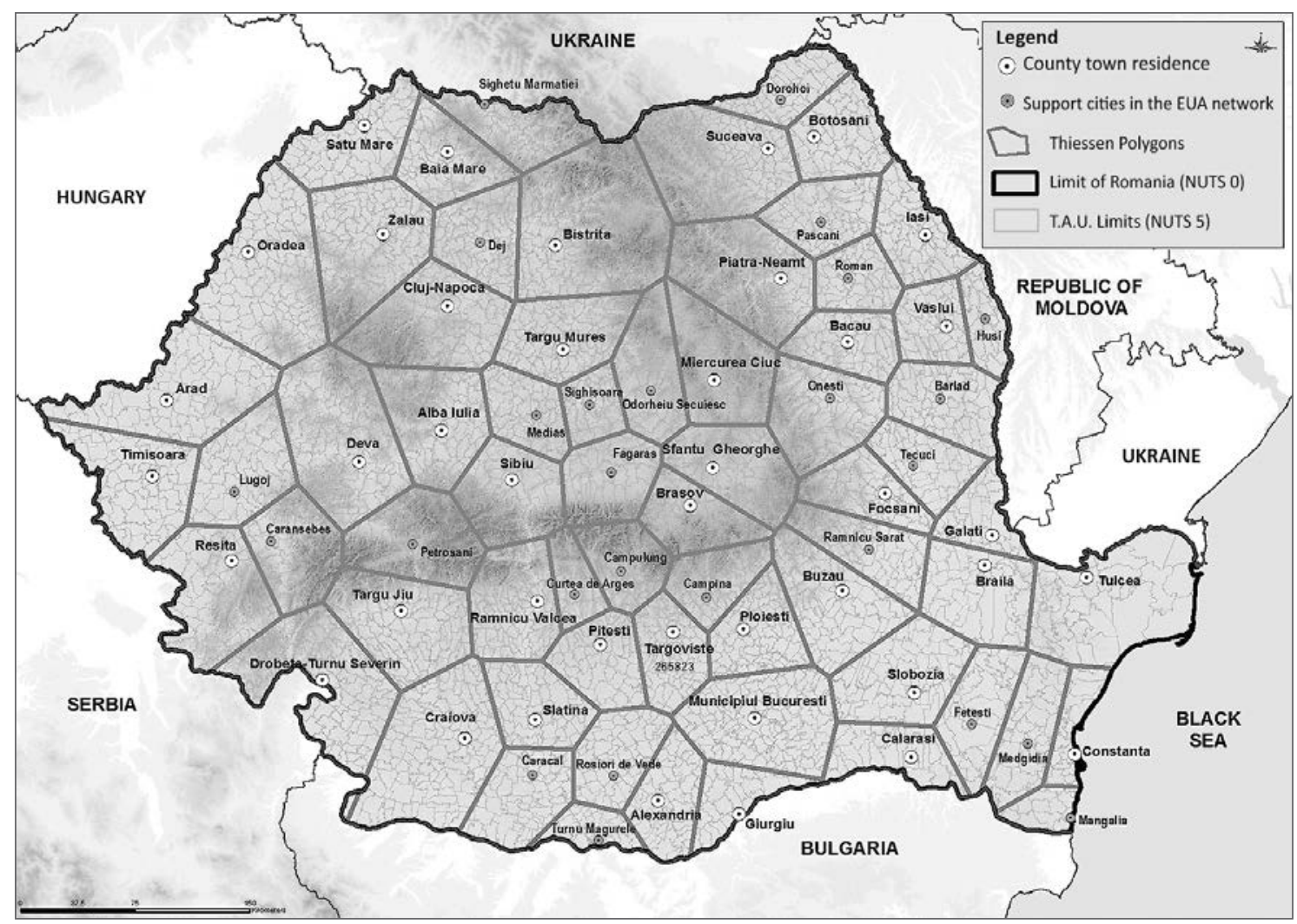

Source: Calculated by the authors; own design

Figure 4: Service areas in Romania

a rather low degree of polycentricity. The following results were obtained from the linear regression between the accessibility of centres of functional urban areas and the decimal logarithm of the population of functional urban areas:

\section{Regression equation: Accessibility $=2.293955+0.256645 \lg ($ Population $)$ \\ Slope $=0.256645$}

The slope of the regression line between the accessibility of the functional urban areas centres and the decimal logarithm of the population of functional urban areas is small, 0.256645 . Thus, the accessibility of functional urban areas centres does not depend on the population of functional urban areas to which they belong. Consequently, the second indicator of connectivity shows a high degree of polycentricity in Romania.

The connectivity index reflects the accessibility of urban centres within the national settlement network and European transport networks, and depends on the national and European transport and communication policies. Its value (60.7) shows an improvement in 2016 compared to its 2001 value in ESPON 1.1.1 (46.6). Nevertheless, the value for Ro- 
mania is still lower than the average value in the European Union; the difference shows the need to focus national policies on improving both local and "greater" transport networks. The capital, Bucharest, plays the main role in the national urban hierarchy, dominating the economic and administrative networks, and its national and international accessibility is significantly better compared to other Romanian cities.

\subsection{Measuring polycentricity}

The seven sub-indicators were transformed into utilities, which were aggregated into the indices of the three dimensions of polycentricity (size, location and connectivity) used to build up the Polycentricity Index. Table 3 compares the values of indices obtained in this study with those determined in the ESPON Project 1.1.1 (Nordregio 2004).

\begin{tabular}{|l|c|c|c|c|}
\hline \multirow{2}{*}{\multicolumn{1}{|c|}{ Index }} & \multicolumn{2}{|c|}{ Variant in the paper } & \multicolumn{2}{c|}{$\begin{array}{c}\text { Variant in ESPON Project 1.1.1 } \\
\text { (Nordregio2004) }\end{array}$} \\
\cline { 2 - 5 } & $\begin{array}{c}\text { Value of } \\
\text { the index }\end{array}$ & $\begin{array}{c}\text { The place occupied in } \\
\text { the ranking of ESPON } \\
\text { countries }\end{array}$ & $\begin{array}{c}\text { Value of } \\
\text { the index }\end{array}$ & $\begin{array}{c}\text { The place occupied in } \\
\text { the ranking of ESPON } \\
\text { countries }\end{array}$ \\
\hline Size Index & 82.4 & 8 & 78.3 & 11 \\
\hline Location Index & 78.4 & 12 & 80.9 & 10 \\
\hline Connectivity Index & 60.7 & 16 & 46.6 & 24 \\
\hline Polycentricity Index & 73.2 & 5 & 66.3 & 13 \\
\hline
\end{tabular}

Readers should be aware that the computations in the paper and ESPON Project 1.1.1 use different methodologies.

Source: Computed by the authors

Table 3: Results of measuring polycentricity in Romania

Except for the Connectivity Index values, for which there is a difference of 14.1 in favour of this study, the values of the other indices show only slight differences from the previous results. Also, for the Location Index only, the value in ESPON Project 1.1.1 is higher than the value in this paper, most likely due to the change of the number of functional urban areas, and for the other indices the differences are in the opposite sense.

Furthermore, one could question the differences between the rankings for each component individually. Indeed, in many ESPON countries there are large or even very large differences between two or even all three components of polycentricity. Polycentricity is investigated through the three dimensions, namely the size, location and connectivity of functional urban regions (FUAs). The three dimensions refer to different aspects of polycentricity, which are not correlated and together make up the polycentricity. Therefore, it is not abnormal and strange that there are even major differences between the three indices of a given country. The Polycentricity Index encompasses all components of polycentricity as a geometric mean. 


\subsection{The strength of the relationship between accessibility, turnover and population}

The Pearson correlation coefficient was computed to measure the intensity of the correlation between accessibility, turnover and population, as in the methodology used by ESPON Project 1.1.1 (Nordregio 2004). The results are presented in Table 4. As shown in the table, all correlation coefficients are significant at $\alpha=0.01$. The value of the correlation coefficient between population and turnover very close to $1(0.967)$ indicates a strong correlation between the two variables. For this reason, it can be said that a more economically developed functional urban area has a larger population. At the same time, there are weak positive relationship between population and accessibility $(0.308)$, as well as between turnover and accessibility (0.342), which means that more economic developed or more populated functional urban areas do not necessarily have higher accessibility.

\begin{tabular}{|c|c|c|c|}
\cline { 2 - 4 } \multicolumn{1}{c|}{} & Accessibility & Turnover & Population \\
\hline \multirow{2}{*}{ Accessibility } & - & $0.342^{* *}$ & $0.308^{* *}$ \\
& & 0.004 & 0.010 \\
\hline \multirow{2}{*}{ Turnover } & & - & $0.967^{* *}$ \\
& & & 0.000 \\
\hline \multirow{2}{*}{ Population } & & & - \\
\hline
\end{tabular}

${ }^{* *}$ Correlation is significant at the 0.01 level (2-tailed)

Source: Computed by the authors

Table 4: Correlation between accessibility, turnover and population

The findings indicate a growth of the Romanian polycentricity index due to the improvement of the accessibility of the urban settlements network (TACHE and PETRIşor 2017). Moreover, they show a rapid economic development of the regional development poles, which is a premise for a balanced territorial development. Spatial planning specialists claim that polycentricity depends at large on connectivity - more exactly, on the frequency and form of exchanges between the urban centres (TACHE and TACHE 2016), sustaining the need for connecting the transportation and spatial planning strategies (MARTNER 2016).

In order to assess adequately the polycentricity of the Romanian polycentric network, future studies should also include a GIS-based analysis of the national territorial accessibility and an up-to-date territorial diagnosis of the functional urban areas (TACHE and TACHE 2016), including an analysis of smart territorial specialisations.

\subsection{Methodological considerations}

ESPON Project 1.1.1 (Nordregio 2004) is developed by a large team of specialists, which means that the work has a high scientific value. For this reason, it is hard to criticise the 
ESPON approach. In this paper, we have made some changes to the ESPON methodology, which, in our opinion, improves it. For an urban system to be polycentric, an important condition is not to have a dominant centre within that territory. In any territory where polycentricity is studied, there is a great diversity of the size of settlements, from small to large ones.

The lower the slope of the regression line, the higher is the level of polycentricity. The slope of the regression line is smaller when there are no large differences between the sizes of the settlements ranked consecutively in the top in terms of the size. To some extent, this is happening almost always. For this reason, primacy has a considerably greater importance than the slope of the regression line. At the same time, one cannot say that the slope has a higher accuracy than the primacy. It is hard to tell that, if the primacy weighs four times more than the slope of the regression line, this ratio has a large value.

However, the choice of the weights of indices and indicators is in general the subject of a collective action, which makes the emergence of questionable issues less likely. Also, in order to compare the values of partial polycentricity indices and Polycentricity Index with the values of similar indices of the ESPON countries, we needed to use the same weights of the required indices and indicators. Because the most straightforward prerequisite of polycentricity is a distribution including large and small cities, it is necessary to use all functional urban regions (FUAs) when computing the regression line. From a statistical point of view, at least 15 pairs of observations are required to compute a linear regression, but most of the times over 25 to 30 pairs were used.

\subsection{Limitations and future directions}

One of the limitations of the study is the particular situation of Romania, where Bucharest stands out as an outlier in territorial analyses, concentrating one tenth of the total population, but a more important share of the resources and economic activities; its hypertrophic dimension modifies the general values of statistical analysis. One possible solution is to exclude it from future analyses, although its influence on other areas is significant, but cannot be discerned by the data.

Another limitation is the availability of indicators and data. All territorial studies carried out in Romania are affected by this issue. The source of data, the National Statistical Institute, collects the data based on needs and funds; the shortcoming can only be overcome if other authorities, like those in charge with spatial development, create the need.

Perhaps the main limitation consists of comparing the results obtained using a different methodology, different data and a different coverage (number of functional urban areas, other changes occurred in Romania) with those obtained in ESPON Project 1.1.1. Nevertheless, the methodology used in the study is more suitable in the current Romanian conditions, because (1) smaller functional urban areas are better suited to represent the urban system of Romania, (2) turnover can be computed at the regional level in Romania, while the GDP is not measured, and (3) accessibility computed based on rails and roads is a better indicator of regional connectivity than multimodal accessibility, including also the air accessibility. 
One could ask why not using a good, simple measure of polycentricity that everybody understands instead of a complicated approach, like the one in ESPON Project 1.1.1., or the even more complicated one in this article. The answer is that polycentricity is a dynamic and multifaceted concept, and, therefore, a single measure cannot accomplish the task.

Last but not least, the present study had a merely methodological focus, and the importance of its findings was interpreted in methodological terms. A question of particular importance relates to the relevance of the analyses for spatial planning and regional policies, such as the Romanian Territorial Development Strategy titled "A Polycentric Romania 2035", aimed at developing a more polycentric structure in Romania. Previous theoretical articles addressed the question "How can sustainability goals be translated into spatial policies", and found out that, in terms of polycentricity, it is not clear whether different poles of development should be balanced economically, socially and environmentally, or should there be economic centres, social centres, and environmental centres (PETRIŞOR 2017).

The results of the present study indicate (with their methodological caveats) that Romania has become more polycentric, but different components of polycentricity had different dynamics, resulting into different ranks. These arguments seem to indicate that the natural dynamic creates centres with individual strengths, corresponding to the multifarious character of sustainability. In more general terms, the study may indicate that, in terms of spatial planning, a bottom-up approach (i.e., the natural dynamic of functional urban areas) might, as suggested by FAROLE et al. (2011), help polycentricity more than the top-down directed policies aimed at creating the spatial cohesion in Europe (FALUDI 2004; 2006).

\section{Conclusions}

There is no unanimously accepted definition of polycentricity. One of the reasons for this is the level at which polycentricity is studied: city (especially metropolis), subdivision of the region (e.g. county), region, country etc. Another reason is the large difference between the sizes of official territorial units from one country to another. The wide variety of polycentricity concepts led to a multitude of approaches to measuring the degree of polycentricity of urban systems.

The methodology used for computing the Polycentricity Index in this study was based on the one used in ESPON Project 1.1.1 (Nordregio 2004), with some changes. More exactly, the size of functional urban areas was expressed by the turnover instead of GDP, due to the unavailability of data at the settlement level in Romania. Also, for the assessment of connectivity, multimodal accessibility has been replaced by accessibility since the latter is more suggestive.

In this study, the Polycentricity Index was obtained by aggregating the Size Index, Location Index and Connectivity Index. The Size Index is quite high (82.38), meaning that the size has a fairly uniform distribution in the territory. Thus, Romania would rank $8^{\text {th }}$ in a top of the ESPON Space countries based on this index. The functional urban areas centres are located fairly evenly across the territory, because the Location Index of Romania has 
a relatively high value (78.39). In the top of the Location Index for ESPON countries, Romania would rank $12^{\text {th }}$. The Connectivity Index is 60.71 , which shows a medium connectivity between the centres of the functional urban areas. Thus, Romania would rank $16^{\text {th }}$ in a ranking from this index of the ESPON Space countries.

The Polycentricity Index of Romania has a value of 73.19, which indicates a medium high level, so in the top of the Polycentricity Index in the ESPON countries, Romania would rank $5^{\text {th }}$. This is an advantage for the national policies, given the aim of its territorial strategy to create a polycentric structure of the territory. There are significant differences between the values of indicators and indices obtained for Romania in this study and those of ESPON Project 1.1.1. Romania's Polycentricity Index in this study is higher by 6.9 than Romania's Polycentricity Index in ESPON Project 1.1.1 (Nordregio 2004).

The Polycentricity Index, determined by aggregating the two components (morphological and relational), is a fairly accurate measure of polycentricity. Although the morphological component is consistently quantified, we consider that the Connectivity Index only partially covers the functional component, because the two corresponding indicators are computed based on an indicator of accessibility. This is why a more comprehensive index would lead to a better assessment of polycentricity. This index should aggregate indicators that use commuting data, e.g. Entropy Index or Special Functional Polycentricity.

The Romanian territorial development strategy sets as main target for 2035 a polycentric development of the settlement network in order to meet the goals of the national and European policies on economic competitiveness, social equity, and sustainable development. The "Polycentric Romania" scenario aims for the spatial development of the national territory in areas situated around some nuclei (cores) - large or average cities concentrating human, material, and technological resources, but also capitals by 2035, efficiently interconnected to the European territories.

The present study aimed to provide a realistic assessment of the current level of the polycentricity indices of Romanian functional urban areas, which can be used to support the strategic planning aimed at transposing in the territory the Romanian objectives and development priorities for 2035. Although the concept of polycentricity can easily be applied to territorial planning, the process of polycentric development depends on a large number of drivers; therefore, in order to maximise its benefits, this development must be controlled and directed by adequate policies and strategies (IANOŞ et al. 2016). A continuous monitoring of the local policies for the development of Romanian metropolitan areas is an absolute requirement for correcting the development strategies and improving the local governance (TACHE et al. 2018). Drafting a polycentric development strategy and defining smart functional urban areas can create the national grounds for determining the priorities, goals and needs for developing a functionally efficient polycentric network, directly correlated to the regional and local strategies.

The practical relevance of the study consists of providing a methodology which adapts the valuable approach used in ESPON Project 1.1.1 (cf. Nordregio 2004) to the particularities of Romania, and also to the specificity of its development during the period following the completion of the study. Nevertheless, its application was hindered by the availability 
of national data and indicators; the results are merely a consequence of this situation, but can constitute a starting point. Future studies can improve them if the authorities in charge understand the need for developing new indicators and collect new data at particular territorial levels, and the Government provides adequate funding to the National Institute of Statistics, the Romanian organism in charge with territorial data collection.

\section{Acknowledgment}

This work was supported by a grant of the National Authority for Scientific Research and Innovation - Romania CNCS/CCCDI - UEFISCDI, project number PN-III-P2-2.1PED-2016-0733 PNCDI III.

The authors are thankful to the anonymous reviewers for the time and efforts invested in reviewing the article, and especially for their constructive comments, which have substantially contributed to increasing the readability and addressability of the article, as well as its overall quality.

\section{References}

Aligica P. D., Tarko V. (2012): Polycentricity: from Polanyi to Ostrom, and Beyond. In: Governance, 25 (2), pp. 237-262.

Brezzi M., Veneri P. (2015): Assessing Polycentric Urban Systems in the OECD: Country, Regional and Metropolitan Perspectives. In: European Planning Studies, 23 (6), pp. 1128-1145.

Burgalassi D. (2010): Defining and Measuring Polycentric Regions: The Case of Tuscany. Pisa: University of Pisa, Department of Economic Sciences (= Discussion Paper, 101; = MPRA Paper 25880). - http://mpra.ub.uni-muenchen.de/25880/(access: July 10, 2018).

Burger M. (2011): Structure and Cooptition in Urban Networks. PhD Thesis. Erasmus University Rotterdam. - http://repub.eur.nl/res/pub/26178/ (access: July 10, 2018).

Burger M., De Goei B., van der Laan L., Huisman F. J. (2011): Heterogeneous Development of Metropolitan Spatial Structure: Evidence from Commuting Patterns in English and Welsh City-regions, 1981-2001. In: Cities, 28 (2), pp. 160-170.

Burger M., Meijers E. (2012): Form Follows Function? Linking Morphological and Functional Polycentricity. In: Urban Studies, 49 (5), pp. 1127-1149.

Burger M., Meijers E., van Oort F. G. (2014a): Regional Spatial Structure and Retail Amenities in the Netherlands. In: Regional Studies, 48 (12), pp. 1972-1992.

Burger M., van Der KnAAP B., Wall R. S. (2014b): Polycentricity and the Multiplexity of Urban Networks. In: European Planning Studies, 22 (4), pp. 816-840.

Burger M., van Oort F. G., Wall R. S., Thissen M. J. (2013): Analysing the Competitive Advantage of Cities in the Dutch Randstad by Urban Market Overlap. In: KLAESSON J., Johansson B., Karlsson C., Stough R. (eds): Metropolitan Regions: Knowledge Infrastructures of the Global Economy. Berlin / Heidelberg: Springer, pp. 375-391.

Champion A. G. (2001): A Changing Demographic Regime and Evolving Polycentric Urban Regions: Consequences for the Size, Composition and Distribution of City Populations. In: Urban Studies, 38 (4), pp. 657-677. 
Champion T., Coombes M. (2014): Is Pennine England Becoming More Polycentric or More Centripetal? An Analysis of Commuting Flow in a Transforming Industrial Region, 1981-2001. In: O'Donoghue D. (ed.): Urban Transformations: Centres, Peripheries and Systems. Farnham, UK: Ashgate Publishing, pp. 73-80.

Condeço Melhorado A. M., Demirel H., Kompil M., Navajas E., Christidis P. (2016): The Impact of Measuring Internal Travel Distances on Self-potentials and Accessibility. In: European Journal of Transport and Infrastructure Research, 16 (2), pp. 300-318.

Cowell M. (2010): Polycentric Regions: Comparing Complementarity and Institutional Governance in the San Francisco Bay Area, the Randstad and Emilia-Romagna. In: Urban Studies, 47 (5), pp. 945-965.

CSD - European Spatial Development Perspective (1999): Towards Balanced and Sustainable Development of the Territory of the EU. Luxembourg: Office for Official Publications of the European Communities.

Davoudi S. (2003): Polycentricity in European Spatial Planning: From an Analytical Tool to a Normative Agenda. In: European Planning Studies, 11 (8), pp. 979-999.

de Goei B., Burger M., van Oort F., Kitson M. (2010): Functional Polycentrism and Urban Network Development in the Greater South East, United Kingdom: Evidence from Commuting Patterns, 1981-2001. In: Regional Studies, 44 (9), pp. 1149-1170.

Dobrin M., TAChe A. V., Petrişor A.-I. (2010a): Development Disparities in the Administrative/ Territorial Units in Romania: Hierarchy, Methods, Indicators, Statistical Analysis. In: Romanian Statistical Review, 58 (5), pp. 16-26.

Dobrin M., TAChe A. V., Petrişor A.-I. (2010b): System of Indicators to Analyze Regional Development Disparities in Romania. In: Romanian Statistical Review, 58 (8), pp. 25-37.

DüHR S. (2005): Potentials for Polycentric Development in Europe: The ESPON 1.1.1 Project Report. In: Planning Practice and Research 20 (2), pp. 235-239.

DüHR S., NADIN V. (2005): North West Europe Interreg IIIB. Spatial Vision Working Group. Polycentric Territorial Development (Including Urban-Rural Relationships in NWE), Final Report. Bristol, UK: University of the West of England. - http://3b.nweurope.eu/upload/ documents programme/2479.study_1_final_report.pdf(access: July 10, 2018).

Egnatia Odos Observatory (2010): An Assessment of Egnatia Motorway's Impact on Polycentric Development. - http://observatory.egnatia.gr/reports/2010/polycentricity_report_EN.pdf (access: 10.07.2018).

Eskelinen H., Fritsch M. (2009): Polycentricity in the North-Eastern Periphery of the EU Territory. In: European Planning Studies, 17 (4), pp. 605-619.

FALudi A. (2001): The Application of the ESDP: Evidence from the North West Metropolitan Area. In: European Planning Studies, 9 (5), pp. 663-676.

FALudi A. (2004): Territorial Cohesion: Old (French) Wine in New Bottles? In: Urban Studies, 41 (7), pp. 1349-1365.

FALudi A. (2006): From European Spatial Development to Territorial Cohesion Policy. In: Regional Studies, 40 (6), pp. 667-678.

Farole T., Rodríguez-Pose A., Storper M. (2011): Cohesion Policy in the European Union: Growth, Geography, Institutions. In: Journal of Common Market Studies, 49 (5), pp. 1089-1111.

Franz P., Hornych C. (2010): Political Institutionalisation and Economic Specialisation in Polycentric Metropolitan Regions: The Case of the East German 'Saxony Triangle'. In: Urban Studies, 47 (12), pp. 2665-2682.

Glanzmann L., Grillon N., Kruse C., Thierstein A. (2004): Polycentricity and Metropolitan Governance: A Swiss Case-study. Paper presented at the 44th European Congress of the European Regional Science Association, Porto, Portugal. 
Green N. (2005): Towards a Definition of Polycentricity in Terms of Network Theory, and the Visualisation of Polycentricity Using a GIS. Paper presented at CUPUM 05: Computers in Urban Planning and Urban Management, London. - http://128.40.111.250/cupum/ searchpapers/papers/paper134.pdf (access: July 10, 2018).

Green N. (2007): Functional Polycentricity: A Formal Definition in Terms of Social Network Analysis. In: Urban Studies, 44 (11), pp. 2077-2103.

Hague C., KIRK K. (2003): Polycentricity Scoping Study. London, UK: Office of the Deputy Prime Minister.

Hall P. G., PaIn K. (2006): The Polycentric Metropolis: Learning from Mega-City Regions in Europe. London, UK: Earthscan.

Hanssens H., Derudder B., van Aelst S., Witlox F. (2014): Assessing the Functional Polycentricity of the Mega-City-Region of Central Belgium Based on Advanced Producer Service Transaction Links. In: Regional Studies, 48 (12), pp. 1939-1953.

Holl A. (2007): Twenty Years of Accessibility Improvements. The Case of the Spanish Motorway Building Programme. In: Journal of Transport Geography, 15 (4), pp. 286-297.

IAnoş I. (2017): Causal Relationships Between Economic Dynamics and Migration: Romania as Case Study. In: Domínguez-MujICA J. (ed.): Global Change and Human Mobility. Advances in Geographical and Environmental Sciences, Singapore: Springer, pp. 303-322.

ianoş I., Petrişor A.-I., Zamfir D., Cercleux A. L., Stoica I. V., TĂlângă C. (2013): In Search of a Relevant Index Measuring Territorial Disparities in a Transition Country. Romania as a Case Study. In: Die Erde - Journal of the Geographical Society of Berlin, 144 (1), pp. 69-81.

IAnoş I., Sîrodoev I., Pascariu G., Henebry G. (2016): Divergent Patterns of Built-up Urban Space Growth Following Post-Socialist Changes. In: Urban Studies, 53 (15), pp. 3172-3188.

IGEAT, IGSO, LATTS (2007): Study on Urban Functions - Final Report of ESPON 1.4.3. Luxembourg: ESPON Coordination Unit.

Ipenburg D., LAmbregts B. (2001): Polynuclear Urban Regions in North West Europe: A Survey of Key Actor Views. Delft, The Netherlands: DUP Science (= Housing and Urban Policy Studies Series, 18).

Kauffmann A. (2016): Is the 'Central German Metropolitan Region' Spatially Integrated? An Empirical Assessment of Commuting Relations. In: Urban Studies, 53 (9), pp. 1853-1868.

Kloosterman R. C., Lambregts B. (2001): Clustering of Economic Activities in Polycentric Urban Regions: The Case of the Randstad. In: Urban studies, 38 (4), pp. 717-732.

Kloosterman R. C., Musterd S. (2001): The Polycentric Urban Region: Towards a Research Agenda. In: Urban studies, 38 (4), pp. 623-633.

Korcelli-OlejniczaK E. (2015): On City-Region Relations. Towards the Urban-Rural Region of Warsaw. In: Mitteilungen der Österreichischen Geographischen Gesellschaft, 157, pp. $129-149$.

Kurek S., Wójtowicz M., Galka J. (2017): Does Commuting in Post-Socialist Second-tier Cities Show Signs of Post-suburban Development? Evidence from Cracow. In: Mitteilungen der Österreichischen Geographischen Gesellschaft, 159, pp. 23-53.

Lambregts B. (2009): The Polycentric Metropolis Unpacked: Concepts, Trends and Policy in the Randstad Holland. Amsterdam: Amsterdam Institute for Metropolitan and International Development Studies.

Limtanakool N., Dijst M., Schwanen T. (2007): A Theoretical Framework and Methodology for Characterising National Urban Systems on the Basis of Flows of People: Empirical Evidence for France and Germany. In: Urban Studies, 44 (11), pp. 2123-2145.

Limtanakool N., Schwanen T., Dijst M. (2009): Developments in the Dutch Urban Systems on the Basis of Flows. In: Regional Studies, 43 (2), pp. 179-196. 
Manić E., Popović S., Mitrović Đ (2016): Is there a "Chinese Wall” in Europe? A Glance at the Development of Socio-economic Disparities in Europe. In: Mitteilungen der Österreichischen Geographischen Gesellschaft, 158, pp. 133-148.

Manole S. D., Petrişor A.-I., Tache A. V., PÂrvu E. (2011): GiS Assessment of Development Gaps Among Romanian Administrative Units. In: Theoretical and Empirical Researches in Urban Management, 6 (4), pp. 5-19.

Manole S., Tache A. V., Petrişor A.-I., PÂrvu E. (2012): Geographical Information Systems Assessment of Development Disparities Among Romanian Regions of Development. In: Romanian Review of Regional Studies, 8 (1), pp. 3-16.

Manole S. D. (2017): Polycentricity Issues of Romania's South-East Region. In: Management Strategies, 34 (1), pp. 411-419.

Manole, S. D., Tache, A., Popescu, O. (2018): Evaluating the Romanian Polycentricity Using the Functional Urban Areas Determined on the Basis of Statistical Indicators. In: Romanian Statistical Review Supplement, Romanian Statistical Review, 66 (2), pp. 159-177.

Martner C. (2016): Dispersed Expansion, Diffused City and Transportation: The Case of Queretaro, Mexico. In: Revista EURE - Revista de Estudios Urbano Regionales, 42 (125), pp. $31-60$.

Masip-Tresserra J. (2016): Polycentricity, Performance and Planning Concepts, Evidence and Policy in Barcelona, Catalonia. Delft, The Netherlands: Delft University of Technology.

Maturana F. R., Arenas V. F. (2012): El policentrismo en Chile: medición exploratoria para el sistema de ciudades de las regiones de La Araucanía, de Los Ríos y de Los Lagos. In: Revista de Geografía Norte Grande, 52, pp. 37-56.

MeiJers E. (2005): Polycentric Urban Regions and the Quest for Synergy: Is a Network of Cities More than the Sum of the Parts? In: Urban studies, 42 (4), pp. 765-781.

MeiJers E. (2007): Clones or Complements? The Division of Labour Between the Main Cities of the Randstad, the Flemish Diamond and the RheinRuhr Area. In: Regional Studies, 41 (7), pp. 889-900.

MeiJers E. (2008): Measuring Polycentricity and its Promises. In: European Planning Studies, 16 (9), pp. 1313-1323.

Meijers E., Burger M. (2010): Spatial Structure and Productivity in US Metropolitan Areas. In: Environment and planning A, 42 (6), pp. 1383-1402.

Meijers E., Sandberg K. (2006): Polycentric Development to Combat Regional Disparities? The Relation between Polycentricity and Regional Disparities in European Countries. Paper, presented at the 46th European Regional Science Association Conference, Volos, Greece. https://ideas.repec.org/p/wiw/wiwrsa/ersa06p287.html (access: July 10, 2018).

Meijers E., SAndberg K. (2008): Reducing Regional Disparities by Means of Polycentric Development: Panacea or Placebo? In: Scienze Regionali, 7 (2), pp. 71-96.

Meijers E., Waterhout B., Zonneveld W. A. M. (2005): Polycentric Development Policies in European Countries: An Introduction. IN: Built Environment, 31 (2), pp. 97-102.

Meijers E., Waterhout B., Zonneveld W. A. M. (2007): Closing the Gap: Territorial Cohesion Through Polycentric Development. In: European Journal of Spatial Development, 24, pp. $1-24$.

Nordregio - Nordic Centre for Spatial Development (2004, revised version 2005): ESPON 1.1.1 - Potentials for Polycentric Development in Europe. Final Project Report. Stockholm: Nordregio.

Palma P., Rauhut D., Humer A. (2015): Polycentricity and Social Services of General Interest: A Multivariate Analysis. Paper prepared for the 55th European Congress of Regional Science International, 25-29 August 2015, Lisbon, Portugal. 
PARr J. (1985): A Note of the Size Distribution of Cities Over Time. In: Journal of Urban Economics, 18 (2), pp. 199-212.

PARr J. (2004): The Polycentric Urban Region: A Closer Inspection. In: Regional studies, 38 (3), pp. 231-240.

Patuelli R., Reggiani A., Nijkamp P., Bade F. J. (2010): The Evolution of the Commuting Network in Germany: Spatial and Connectivity Patterns. In: Journal of Transport and Land Use, 2 (3/4), pp. 5-37.

Petrişor A.-I. (2017): A Diversity-Based Approach to the Spatial Development of Socio-Ecological Systems. In: Urbanism Architecture Constructions, 8 (2), pp. 143-162.

Raunut D. (2016): Polycentricity: A Critical Discussion. Paper prepared for the 56th Congress of the European Regional Science Association, 23-26 August 2016, Vienna, Austria.

RePUS - Regional Polycentric Urban System (2007): INTERREG III B. Strategy for a Regional Polycentric Urban System in Central Eastern Europe Economic Integrating Zone. Final report. - http://www.repus.it/repus-docs/repus_finalreport.pdf (access: July 10, 2018)

Sandberg K., MeiJers E. (2006): Polycentric Development: Panacea for Regional Disparities in European Countries. Paper presented at the $10^{\text {th }}$ UNECE Conference on Urban and Regional Research, May 22-23, 2006, Bratislava, Slovakia.

Schürmann C., Spiekermann K., Wegener M. (1997): Accessibility Indicators. Dortmund, Germany: Institut für Raumplanung der TU Dortmund (IRPUD) [Institute of Spatial Planning, Technical University of Dortmund] (= Berichte aus dem Institute für Raumplanung, 39.

Shaw D., Sykes O. (2004): The concept of Polycentricity in European Spatial Planning: Reflections on its Interpretation and Application in the Practice of Spatial Planning. In: International Planning Studies, 9 (4), pp. 283-306.

Sîrodoev I., IAnoş I., White G., VîRdol D. (2017): Foreign Direct Investment as a Factor of Diminishing or/and Increasing Regional Inequalities? In: JORDAN P. (ed.): 10 Years of EU Eastern Enlargement. The Geographical Balance of a Courageous Step. Proceedings of the Symposion in Vienna, Dec. 3-4, 2017. Vienna: Austrian Academy of Sciences Press, pp. 269-286 (= ISR-Forschungsberichte, 42).

SPIEKERMANn K., Schürmann C. (2007): Update of Selected Potential Accessibility Indicators. Final Report. Dortmund, Germany: Spiekermann \& Wegener Urban and Regional Research (S\&W).

Spiekermann K., Wegener M. (2006): Accessibility and Spatial Development in Europe. In: Scienze Regionali, 5 (2), pp. 15-46.

Tache A. V., Manole S. D., Petrişor A.-I. (2018): Metropolization of Large Urban Centers in Romania: Analyses and Solutions. In: Algerian Journal of Engineering, Architecture and Urbanism, 2 (1), pp. 8-17.

Tache A. V., Petrişor A.-I. (2017): GIS-Based IT Model for Assessing Territorial Accessibility in Romania. In: International Journal of Human Settlements, 1 (2), pp. 13-23.

Tache A. V., Popescu O. C., Tache M. (2017): GIS Mathematic Model Analyzing the Attractiveness of the Romanian Settlements Network, Assessing the Competitiveness Factors at National Level. In: Romanian Statistical Review Supplement, Romanian Statistical Review, 65 (9), pp. 83-102.

TAChe A. V., TACHE M. (2016): A Methodology for the Evaluation of Functional Urban Areas in Romania. In: Romanian Journal of Geography, 60 (1), pp. 73-83.

Taubenböck H., Standfuss I., Wurm M., Krehl A., Siedentop S. (2017): Measuring Morphological Polycentricity - A Comparative Analysis of Urban Mass Concentrations Using Remote Sensing Data. In: Computers, Environment and Urban Systems, 64, pp. 42-56.

vAN DER LAAN L. (1998): Changing Urban Systems: An Empirical Analysis at two Spatial Levels. In: Regional Studies, 32 (3), pp. 235-247. 
van Nuffel N., Saey P., Derudder B., Devriendt L., Witlox F. (2010): Measuring Hierarchical Differentiation: Connectivity and Dominance in the European Urban Network. In: Transportation Planning and Technology, 33 (4), pp. 343-366.

van Oort F. G., Burger M., RasPe O. (2010): On the Economic Foundation of the Urban Network Paradigm: Spatial Integration, Functional Integration and Economic Complementarities Within the Dutch Randstad. In: Urban Studies, 47 (4), pp. 725-748.

Vasanen A. (2012): Functional Polycentricity: Examining Metropolitan Spatial Structure Through the Connectivity of Urban Sub-centres. In: Urban Studies, 49 (16), pp. 3627-3644.

Vasanen A. (2013): Spatial Integration and Functional Balance in Polycentric Urban Systems: A Multi-Scalar Approach. In: Tijdschrift voor economische en sociale geografie, 104 (4), pp. 410-425.

Veneri P., Burgalassi D. (2011): Spatial Structure and Productivity in Italian NUTS-3 Regions. In: Working Papers no. 264, Ancona, Italy, Università Politecnica delle Marche, pp. 1-26.

Veneri P., Burgalassi D. (2012): Questioning Polycentric Development and its Effects. Issues of Definition and Measurement for the Italian NUTS-2 Regions. In: European Planning Studies, 20 (6), pp. 1017-1037.

Wegener M. (2013): Polycentric Europe: More Efficient, More Equitable and More Sustainable? Paper presented at the seminar "Welfare and Competitiveness in the European Polycentric Urban Structure: Which Role for Metropolitan, Medium and Small Cities?", Istituto Regionale Programmazione Economica della Toscana (IRPET), 7 June 2013, Florence, Italy.

Wegener M., Eskelinnen H., Fürst F., Schürmann C., Spiekermann K. (2002): Criteria for the Spatial Differentiation of the EU Territory: Geographical Position. Bonn, Germany: Bundesamt für Bauwesen und Raumordnung [Federal Office for Building and Regional Planning] (= BBR-Forschungen 102.2). 